\title{
Stability of Retained Austenite in High-Strength Martensitic Steels with Low Ms Temperature
}

\author{
Dagmar Bublíková, Bohuslav Mašek, Ivan Vorel, Štěpán Jeníček \\ University of West Bohemia, RTI-Regional Technological Institute, Univerzitní 22, CZ - 30614 Pilsen, Czech Republic, \\ E-mail: dagmar.bublikova@seznam.cz
}

An important factor in enhancing the mechanical properties of high-strength steels is the stabilization of an appropriate amount of metastable retained austenite in martensitic matrix. Various novel heat treatment and thermomechanical processing routes have been developed recently which benefit from the effects of retained austenite in terms of achieving better elongation at still high ultimate strength levels. One of these procedures is the $Q \& P$ process (Quenching and Partitioning). It produces martensite and retained austenite to obtain strengths of more than $2000 \mathrm{MPa}$ and elongation levels of about $10 \%$. For this investigation, four steels with low Ms temperatures have been selected. Their chemistries contained manganese, silicon, molybdenum and chromium. The development of heat treatment sequences involved trials with various austenitizing temperatures, cooling rates, quenching temperatures, and carbon partitioning temperatures for the stage in which austenite becomes stabilized. The experimental heat treatment led to microstructures consisting of martensite with retained austenite in all the steels. Their strengths were in the range of 1750-2400 MPa and their A5mm elongation was 10-15\%. The largest fraction of retained austenite, according to $\mathrm{X}$-ray diffraction, was $10 \%$. Specimens with the largest fraction of retained austenite obtained from one schedule were used for studying the stability of retained austenite under cold and hot.

Keywords: Q-P process, retained austenite, AHSS, X-ray diffraction

\section{Acknowledgement}

The present contribution has been prepared under project LO1502 'Development of the Regional Technological Institute' under the auspices of the National Sustainability Programme I of the Ministry of Education of the Czech Republic aimed to support research, experimental development and innovation.

\section{References}

[1] XIONG, Z. P.; KOSTRYZHEV A. G.; SALEH A. A.; CHEN L.; PERELOMA E. V. (2016). Microstructures and mechanical properties of TRIP steel produced by strip casting simulated in the laboratory, Materials Science \& Engineering A, 2016, vol. 664, pp. 26-42.

[2] MAŠEK, B., JIRKOVÁ, H., HAUSEROVÁ, D., KUČEROVÁ, L., KLAUBEROVÁ, D. (2010). The Effect of $\mathrm{Mn}$ and Si on the Properties of Advanced High Strength Steels Processed by Quenching and Partitioning. Materials Science Forum, 2010, Vols. 654-656, pp. 94-97.

[3] JIRKOVÁ, H. et al. (2014). Influence of metastable retained austenite on macro and micromechanical properties of steel processed by the Q-P process, Journal of Alloys and Compounds, available online, Journal of Alloys and Compounds, 615 (2014) pp.163-S168

[4] QIAN, Z.; LIHE Q.; JUN T.; JIANGYING M.; FUCHENG Z. (2013). Inconsistent effects of mechanical stability of retained austenite on ductility and toughness of transformation-induced plasticity steels, Materials Science \& Engineering A, 2013, vol. 578, pp. 370-376.

[5] ORAVCOVÁ, M., PALČEK, P., KRÓL, M. (2016). Dilatometric Measurements of Austenitic Stainless Steel as a Function of Temperature. In Manufacturing Technology, Vol. 16, No. 1, pp. 230-234.

[6] HANUS, P., SCHMIDOVA, E. (2016). Influence of the Welding Process on the Martensitic and Dual Phase High Strength Steels E. In Manufacturing Technology, Vol. 16, No. 4, pp. 702-707.

[7] PALČEK, P., ORAVCOVÁ, M., CHALUPOVÁ, M., UHRÍČIK, M. (2016). The Usage of SEM for Fatigue Properties Evaluation of Austenitic Stainless Steel AISI 316L. In Manufacturing Technology, Vol. 16, No. 5, pp. $1110-1115$. 